\title{
MEWUJUDKAN KEMANDIRIAN PEMUDA BERBASIS TECHNOPRENEUR MELALUI PELATIHAN TUNE UP SEPEDA MOTOR DI KARANG TARUNA LABUHBARU BARAT PEKANBARU
}

\author{
Jusnita*, Denur, Siti Samsiah \\ Prodi Teknik Otomotif, Fakultas Teknik \\ Universitas Muhammadiyah Riau \\ email: jusnita@umri.ac.id
}

\begin{abstract}
Obstacles and challenges that challenge the Labuhbaru Barat coral reef, Payung Sekaki District, among others; (a) Youth activities are still more creative; (B) There is still a limited number of professional cadres related to their role as agents of reform (agents of change) in the implementation of social welfare for community empowerment through the development of productive economic ventures; (c) lack of responsiveness of community attitudes towards improving the quality of youth groups. The result of devotion is individual and social conversation $90 \%$ of participants showed the category of "good", $7.5 \%$ according to the category of "enough" and only $2.5 \%$ of participants who showed the category of "Poor". $100 \%$ of participants showed good training and enthusiasm. After attending the training, the trainees must have abilities in aspects; (1) personal skills capable of repairing and repairing motorcycles related to mechanical skills, among others, are published; tune up system, engine system, electrical system, and chassis system, (2) social skills, namely the ability to communicate with other business units, have the ability to communicate and negotiate with customers (customers), (3) navigation skills as having the ability to overcome problems, for example if there are technical errors in the maintenance and repair of motorbikes and have difficulty learning from mistakes (trial and error). And (4) Vocational prowess, namely having the speed of completing one motorcycle service product.
\end{abstract}

Keywords: Youth, Motorcycle tune up training, techonopreneur

\begin{abstract}
Abstrak
Kendala dan tantangan yang dihadapi karang taruna Labuhbaru Barat Kecamatan Payung Sekaki antara lain; (a) Kegiatan karang taruna masih lebih bersifat rekreatif; (b) Masih kurangnya kader profesional terutama terkait dengan perannya sebagai agen pembaharu (change agent) dalam penyelenggaraan kesejahteraan sosial utamanya pemberdayaan masyarakat melalui pengembangan usaha ekonomi produktif; (c) kurang tanggapnya sikap masyarakat terhadap pengembangan kualitas karang taruna. Hasil dari pengabdian adalah kecakapan individu dan sosial 90\% peserta latih menunjukkan kategori "baik", 7,5\% berada pada kategori "cukup" dan hanya 2,5\% peserta yang menunjukkan kategori "Kurang”. 100\% peserta latih menunjukkan disiplin dan semangat yang baik. Setelah mengikuti pelatihan, peserta pelatihan telah memiliki kemampuan dalam aspek; (1) kecakapan personal yaitu mampu memelihara dan memperbaiki sepeda motor yang berkaitan dengan keterampilan mekanik antara lain meliputi; system tune up, system engine, system kelistrikan, dan system chasis, (2) kecakapan sosial yaitu memiliki kemampuan bekerjasama dengan unit usaha lain, memiliki kemampuan berkomunikasi dan negoisasi dengan pelanggan (customer), (3) kecakapan akademik yaitu memiliki kemampuan memecahkan masalah, misalnya jika terjadi kesalahan teknis dalam pemeliharaan dan perbaikan sepeda motor dan memiliki keberanian belajar dari kesalahan (trial and error). Dan (4) kecakapan Vokasional yaitu memiliki kemampuan kecepatan menyelesaikan satu produk jasa service sepeda motor.
\end{abstract}

Kata Kunci : Karang taruna, Pelatihan tune up sepeda motor, techonopreneur 


\section{PENDAHULUAN}

Karang taruna sebagai wadah pembinaan generasi muda. Pemuda merupakan sumber daya manusia potensial yang tergabung dalam wadah karang taruna, dan belum banyak diberdayakan sebagai agen pembaharu (change agent) dalam program dan kegiatan pemberdayaan masyarakat, khususnya dalam mengembangkan usaha ekonomi produktif dalam rangka mewujudkan kemandirian pemuda yang berbasis technopreneur melalui pelatihan tune up sepeda motor dan pengembangan kesempatan berusaha serta perluasan lapangan kerja di kelurahan. Dengan keberadaannya karang taruna mestinya dapat menjadi kekuatan dominan sebagai lembaga pemberdayaan masyarakat, sebab selain merupakan mitra pemerintah yang mendapat dukungan dan fasilitas, karang taruna juga didukung potensi SDM yang cukup besar.

Menurut Peraturan Menteri Sosial RI Nomor : 77/HUK/2010 tentang Pedoman Dasar Karang Taruna, tugas pokok dan fungsi karang taruna adalah menyelenggarakan pembinaan pemuda dan kesejahteraan sosial melalui pengembangan dan peningkatan usaha ekonomi produktif (UEP). Dalam melaksanakan fungsi penyelenggaraan kesejahteraan sosial dimaksud, kedudukan karang taruna merupakan mitra pemerintah yang dibina dan difasilitasi oleh pemerintah. Dengan demikian, karang taruna sudah memenuhi persyaratan untuk dapat dikembangkan atau diberdayakan sebagai infrastruktur sosial di Kelurahan.

Masih banyak kendala dan tantangan yang dihadapi karang taruna Labuhbaru Barat Kecamatan Payung Sekaki antara lain; (a) Kegiatan karang taruna masih lebih bersifat rekreatif dan hanya sekadar pengisi waktu luang; (b) Masih kurangnya kader profesional terutama terkait dengan perannya sebagai agen pembaharu (change agent) dalam penyelenggaraan kesejahteraan sosial utamanya pemberdayaan masyarakat melalui pengembangan usaha ekonomi produktif; (c) kurang tanggapnya sikap masyarakat terhadap pengembangan kualitas karang taruna; dan (d) masih adanya keraguan pemerintah kelurahan terhadap potensi karang taruna.

Melalui organisasi karang taruna tersebut dapat dilakukan pembinaan dan pengembangan serta pemberdayaan dalam upaya mengembangkan kegiatan sosial, ekonomi produktif untuk mewujudkan kemandirian pemuda yang berbasis technopreneur melalui pelatihan tune up sepeda motor dan minimnya jumlah bengkel sepeda motor sedangkan populasi sepeda motor yang banyak, dengan tumbuhnya sekolahsekolah dari SD, SMP, MA dan SMA/SMK maka tentunya merupakan sebuah peluang yang bagus untuk berwirausaha berbengkelan didaerah tersebut. Disamping itu juga masih banyak pemuda produktif disana dalam status pengangguran yang memang tidak memiliki bekal ketrampilan vokasi.

Melihat permasalahan diatas, maka perlu dilakukan kegiatan pengabdian kepada masyarakat khususnya untuk pemuda karang taruna dalam bentuk:

1. Pelatihan Keterampilan tune up sepeda motor yang berbasis technopreneur

2. Memberikan motivasi untuk mengembangkan skill dalam bentuk usaha perbengkelan.

3. Memberikan pendampingan dalam pengembangan usaha perbengkelan selama dua bulan dengan target kemandirian total.

Dengan konsep ini diharapkan pemuda karang taruna dapat memberikan manfaat bagi masyarakat disekitarnya dalam bentuk kegiatan yang positif dalam arti meningkatkan ekonomi masyarakat di Kelurhan 
Kecamatan Payung Sekaki dan mengurangi angka pengangguran di Kota Pekanbaru khususnya di Keluruhan Labuhbaru Barat Kecamatan Payung Sekaki.

\section{METODE PENGABDIAN}

Metode yang digunakan dalam pengabdian ini adalah metode brainstorming dalam pelatihan dan konsep-konsep manajemen bengkel atau technopreneur.. Dalam setiap langkah, baik itu pelatihan dan techonpreneur konsultasi akan menjadi rujukan paling penting sebagai metode kualitatif.

Untuk penerapan metode kuantitatif, akan didukung oleh data-data berupa kuestionare dari konsumen untuk menganalisa kepuasan pelanggan terhadap penerapan manajemen operasional yang baru dan juga tenaga kerja sendiri terhadap penerapan manajemen sumber daya manusia.

Metode pelatihan untuk Tune Up sepeda motor menggunakan; 1) Metode ceramah dan tanya jawab dengan menyajikan teori secara umum. Teori yang disampaikan adalah engine sepeda motor, pengenalan alat dan penggunaannya serta keselamatan kerja. 2) Metode resitasi dan diskusi dimana tugas diberikan kepada peserta dalam bentuk modul pelatihan yang telah dilengkapi dengan petunjuk dan gambar kerja. 3) Metode demonstrasi; merupakan sistem penyajian sub kerja pelayanan sepeda motor dengan teknis memperagakan kepada peserta. Sub kerja pelayanan sepeda motor terdiri dari; Overhaul Engine, Service berkala dan perawatan, 4) Metode pratikum; peserta yang sudah dilengkapi dengan modul, langsung melakukan praktek dibawah bimbingan instruktur/dosen.

\section{HASIL DAN PEMBAHASAN}

Kegiatan monitoring dan evaluasi dilakukan secara on-going, yaitu selama kegiatan pelatihan berlangsung.
Instrumen yang digunakan meliputi observasi langsung, skala sikap dan tes yang diberikan langsung oleh tim pelaksana. Hasil kegiatan monitoring dan evaluasi pada setiap materi pelatihan seperti pada Tabel dibawah ini: Tabel 1. Hasil Monitoring dan Evaluasi Life Skill

\begin{tabular}{|c|c|c|}
\hline $\begin{array}{c}\text { Materi } \\
\text { Pelatihan }\end{array}$ & Indikator & Hasil \\
\hline $\begin{array}{l}\text { Teori } \\
\text { (system } \\
\text { tune up, } \\
\text { engine, } \\
\text { kelistrikan, } \\
\text { chasis }\end{array}$ & $\begin{array}{l}\text { Bekerjasama } \\
\text { dalam } \\
\text { mendianogsi } \\
\text { s meliputi; } \\
\text { system tune } \\
\text { up, engine, } \\
\text { kelistrikan, } \\
\text { chasis }\end{array}$ & $\begin{array}{l}\text { Sikap } \\
\text { Bekerja sama } \\
\text { dalam kelompok } \\
\text { dengan baik dan } \\
\text { benar } \\
\text { Keterampilan } \\
\text { Terampil dalam } \\
\text { mendianogsis } \\
\text { keterkaitan system } \\
\text { tune up, engine, } \\
\text { kelistrikan, chasis } \\
\text { sepeda motor. } \\
\text { Pengetahuan } \\
\text { Kemampuan } \\
\text { memahami } \\
\text { konsep system } \\
\text { tune up, engine, } \\
\text { kelistrikan, chasis } \\
\text { sepeda motor. }\end{array}$ \\
\hline $\begin{array}{l}\text { Praktek } \\
\text { (system } \\
\text { tune up, } \\
\text { engine, } \\
\text { kelistrikan, } \\
\text { chasis dan } \\
\text { pengecatan }\end{array}$ & $\begin{array}{l}\text { Ketelitian } \\
\text { dan } \\
\text { keseriusan } \\
\text { menjalankan } \\
\text { instruksi dari } \\
\text { setiap } \\
\text { instruktur. }\end{array}$ & $\begin{array}{l}\text { Sikap } \\
\text { Teliti dan serius } \\
\text { dalam bekerja } \\
\text { baik secara } \\
\text { mandiri maupun } \\
\text { berkelompok. } \\
\text { Keterampilan } \\
\text { Terampil } \\
\text { menganalisis } \\
\text { masalah, jika } \\
\text { terjadi kesalahan } \\
\text { teknis dalam } \\
\text { pemeliharaan dan } \\
\text { perbaikan sepeda } \\
\text { motor }\end{array}$ \\
\hline Life Skill & $\begin{array}{l}\text { Menerima } \\
\text { dan mampu } \\
\text { menjelaskan } \\
\text { konsep dasar } \\
\text { tentang } \\
\text { pemahaman } \\
\text { individu, } \\
\text { dinamika } \\
\text { kelompok } \\
\text { kreativitas }\end{array}$ & $\begin{array}{l}\text { Sikap } \\
\text { Menerima konsep } \\
\text { dasar life skill, dan } \\
\text { berkomunikasi, } \\
\text { sistematis, dan } \\
\text { komunikatif dalam } \\
\text { meyampaikan ide- } \\
\text { ide. }\end{array}$ \\
\hline
\end{tabular}




\begin{tabular}{|c|c|c|}
\hline & $\begin{array}{l}\text { dan } \\
\text { kemampuan } \\
\text { psikomotori } \\
\text { k. }\end{array}$ & $\begin{array}{l}\text { Pengetahuan } \\
\text { Memahami } \\
\text { elemen-elemen } \\
\text { perubahan nilai } \\
\text { dan karakter yang } \\
\text { diperlukan untuk } \\
\text { meningkatkan } \\
\text { kesejahteraan dan } \\
\text { kehidupan yang } \\
\text { bermutu. }\end{array}$ \\
\hline $\begin{array}{l}\text { Kecakapa } \\
\mathrm{n} \\
\text { Kewiraus } \\
\text { ahaan }\end{array}$ & $\begin{array}{l}\text { Memahami } \\
\text { dan mampu } \\
\text { menjelaskan } \\
\text { konsep dasar } \\
\text { tentang } \\
\text { perspektif } \\
\text { kewirausaha } \\
\text { an, inovasi } \\
\text { dan strategi } \\
\text { usaha serta } \\
\text { manajemen } \\
\text { bengkel }\end{array}$ & $\begin{array}{l}\text { Sikap } \\
\text { Memahamai } \\
\text { konsep dasar } \\
\text { kewirausahaan, } \\
\text { berkomunikasi, } \\
\text { sistematis, dan } \\
\text { komunikatif } \\
\text { dalam } \\
\text { meyampaikan ide- } \\
\text { ide. } \\
\text { Pengetahuan } \\
\text { Memahami } \\
\text { elemen-elemen } \\
\text { penting tentang } \\
\text { perubahan nilai } \\
\text { dan karakter yang } \\
\text { diperlukan untuk } \\
\text { meningkatkan } \\
\text { kehidupan dan } \\
\text { kesejahteraan } \\
\text { yang bermutu. }\end{array}$ \\
\hline
\end{tabular}

Dari tabel diatas, maka hasil monitoring mengenai kecakapan individu dan kecakapan sosial peserta selama mengikuti pelatihan yang berlangsung dari tanggal 1 sampai dengan 31 September 2019 dapat dinyatakan telah berhasil sesuai dengan rencana yang telah ditetapkan.

Aspek monitoring yang dilakukan adalah; 1) Kedisiplinan dapat mengikuti tata tertib, 2) Penampilan (kerapian ), 3) Kesantunan berperilaku, 4) Kemampuan bekerja sama, 5) Kemampuan berkomunikasi, 6) komitmen, 7) Keteladanan, 8) Semangat, 9) Empati, dan 10) Tanggung jawab.

Hasil monitoring dapat dilihat pada tabel dibawah ini:

Tabel 2. Hasil monitoring dan evaluasi kecakapan individu dan sosial

\begin{tabular}{ccc}
\hline Aspek Yang & \multicolumn{2}{c}{ HASIL PENILAIAN } \\
\cline { 2 - 3 } Di Nilai & Baik Cukup & Kurang \\
\hline
\end{tabular}

\begin{tabular}{|c|c|c|c|}
\hline $\begin{array}{l}\text { Kedisiplinan } \\
\text { (ketaatan } \\
\text { mengikuti tata } \\
\text { tertib) }\end{array}$ & $100 \%$ & - & - \\
\hline $\begin{array}{l}\text { Penampilan } \\
\text { (kerapian dan } \\
\text { kewajaran) }\end{array}$ & $85 \%$ & $10 \%$ & $5 \%$ \\
\hline Berperilaku & $95 \%$ & $5 \%$ & - \\
\hline $\begin{array}{l}\text { Kemampuan } \\
\text { bekerja sama }\end{array}$ & $90 \%$ & $10 \%$ & - \\
\hline $\begin{array}{l}\text { Kemampuan } \\
\text { berkomunikas } \\
\mathrm{i}\end{array}$ & $85 \%$ & $10 \%$ & $5 \%$ \\
\hline Komitmen & $85 \%$ & $10 \%$ & $5 \%$ \\
\hline Keteladanan & $80 \%$ & 15 & $5 \%$ \\
\hline Semangat & $100 \%$ & - & - \\
\hline Empati & $85 \%$ & $10 \%$ & $5 \%$ \\
\hline $\begin{array}{l}\text { Tanggung } \\
\text { jawab }\end{array}$ & $95 \%$ & $5 \%$ & $5 \%$ \\
\hline
\end{tabular}

$\begin{array}{llll}\text { Rata-rata } & \mathbf{9 0 \%} & \mathbf{7 , 5 \%} & \mathbf{2 . 5 \%}\end{array}$

Tabel 5.2 di atas menunjukan bahwa kecakapan individu dan sosial $90 \%$ kategori "baik", 7,5\% berada pada kategori "cukup" dan 2,5\% Peserta yang menunjukkan kategori "Kurang". 100\% peserta latih menunjukkan disiplin dan semangat yang baik. Secara kumulatif, dapat disimpulkan bahwa kegiatan program Pelatihan Tune Up Sepeda Motor Berbasis Technopreneur di Karang Taruna Labuhbaru Barat Pekanbaru yang diselenggarakan atas kerjasama antara Lembaga Pengabdian pada Masyarakat Universitas Muhammadiyah Riau (LPPM UMRI) adalah sebagai berikut; 15 orang peserta pelatihan yang mengikuti kegiatan dari awal sampai akhir telah memiliki kecakapan berupa keterampilan tune up sepeda motor yang dibutuhkan untuk dapat berwirausaha dan mencari kerja.

Bekal pengetahuan tentang tune up dan teknopreneur diharapkan dapat menumbuhkan daya kreativitas peserta pelatih. Kreativitas adalah suatu pertimbangan subjektif dan berkonteks mengenai kebaruan dan nilai hasil dari perilaku individual atau kolektif. Ada lima ciri yang menjadi sifat kemampuan berpikir kreatif: (1) Kelancaran (fluency), (2) Keluwesan (flexibility), (3). Keaslian (originality), 
Penguraian (elaboration),

Perumusan kembali (redefinition).

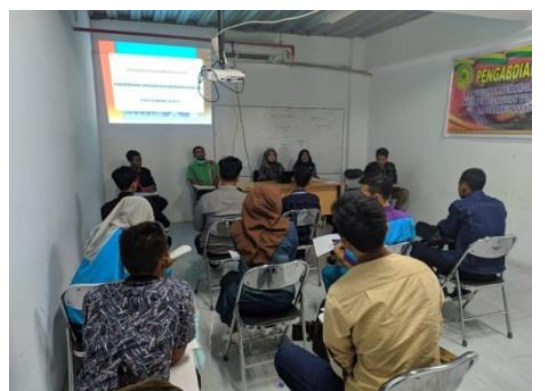

Gambar 2. Pembukaan Pelatihan

Inovasi secara sederhana dapat dipahami sebagai proses pengenalan cara baru dan lebih baik dalam mengerjakan berbagai hal dalam kehidupan di masyarakat. Inovasi tidak selalu berwujud perubahan radikal namun dapat juga berupa perubahan kecil dan sederhana yang melibatkan berbagai komponen lingkungannya. Inovasi tidak harus didominasi perubahan dengan teknologi tinggi, tetapi sentuhan teknologi hanyalah merupakan salah satu faktor inovasi dalam mengelola usaha.

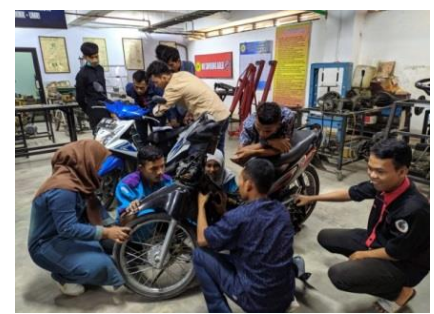

Gambar 3. Peserta Praktek Tune Up Sepeda Motor

Kewirausahaan adalah kemampuan kreatif dan inovatif yang dijadikan dasar, kiat dan sumber daya untuk mencari dan memanfaatkan peluang menuju sukses.

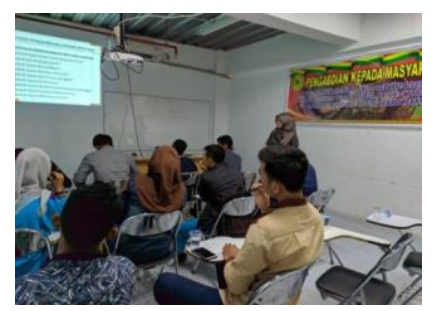

Gambar 4. Pelatihan Kewirausaha
Wirausaha adalah orang yang mempunyai tenaga dan keinginan untuk terlibat dalam petualangan inovatif. Wirausaha juga memiliki kemauan menerima tanggung jawab pribadi dalam mewujudkan keinginan yang dipilih. Bagi pemuda yang realistik hasil yang dapat diterima lebih penting daripada hasil yang sempurna.

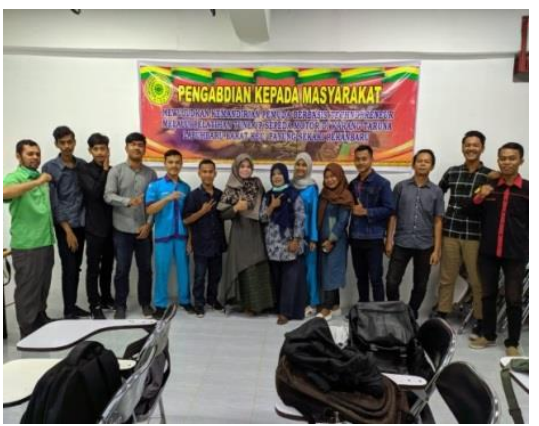

Gambar 5. Penutupan Pelatihan

Jiwa, sikap dan perilaku kewirausahaan memiliki ciri-ciri yakni: (1) penuh percaya diri, dengan indikator penuh keyakinan, optimis, disiplin, berkomitmen dan bertanggungjawab; (2) memiliki inisiatif, dengan indikator penuh energi, cekatan dalam bertindak dan aktif; (3) memiliki motif berprestasi dengan indikator berorientasi pada hasil dan berwawasan ke depan; (4) memiliki jiwa kepemimpinan dengan indikator berani tampil beda, dapat dipercaya dan tangguh dalam bertindak; dan (5) berani mengambil risiko dengan penuh perhitungan.

Ada empat unsur yang membentuk pola dasar kewirausahaan yang benar dan luhur, yaitu: (1) sikap mental, (2) kepemimpinan, (3) ketatalaksanaa dan (4) keterampilan. Secara umum, seorang wirausahawan perlu memiliki ciri percaya diri, berorientasi tugas dan hasil, berani mengambil risiko, memiliki jiwa kepemimpinan, orisinalitas dan berorientasi masa depan. Ciri kebutuhan akan berprestasi meliputi karakter berorientasi laba, ketekunan dan ketabahan, tekad dan kerja keras, motivasi yang besar, energik dan 
inisiatif. Kemampuan mengambil risiko berarti suka pada tantangan. Karakteristik kewirausahaan menyangkut tiga dimensi, yakni inovasi, pengambilan risiko dan proaktif. Kreativitas, inovasi dan jiwa kewirausahaan sangat penting dimiliki pemuda yang tidak dapat melanjutkan sekolah karena sesuatu hal, karena merupakan suatu kemampuan yang sangat berarti dalam proses kehidupan manusia. Makna dan posisi kreativitas dan inovasi Namun masalahnya adalah bagaimana cara kreativitas dan inovasi tersebut dikembangkan dan diimplementasikan dalam kegiatan riil sesuai dengan wawasan kewirausahaan.

Kedelapan anak tangga yang dimaksud adalah: (1) Mau Bekerja Keras. (2) Bekerjasama dengan Orang Lain. (3) Penampilan yang Baik. (4) Percaya Diri. (5) Pandai membuat Keputusan. (6) Mau Menambah Ilmu Pengetahuan. (7) Ambisi untuk Maju (8) Pandai Berkomunikasi.

Etika wirausaha adalah suatu kode etik perilaku aktor berdasarkan nilai-nilai moral dan norma yang dijadikan tuntunan dalam membuat keputusan dan memecahkan persoalan. Ada tiga tingkatan norma etika, yaitu: (1) Hukum, berlaku bagi masyarakat dalam mengatur perbuatan yang boleh atau tidak boleh dilakukan. (2) Kebijakan dan prosedur organisasi, memberi arahan khusus bagi setiap orang dalam organisasi ketika mengabil keputusan. (3) Moral sikap mental individu, sangat penting bagi setiap orang untuk menghadapi suatu keputusan yang tidak diatur oleh aturan formal. Ada sepuluh prinsip etika yang mengarahkan perilaku, yaitu: kejujuran, integritas, menepati janji, kesetiaan, kewajaran/keadilan, suka membantu orang lain, hormat kepada orang lain, bertanggungjawab, mengejar keunggulan dan dapat dipertanggungjawabkan. Sedangkan untuk mempertahankan standar etika dilakukan dengan cara: menciptakan kepercayaan, mengembangkan kode etik, menjalankan kode etik secara adil dan konsisten, melindungi hak-hak perorangan, mempertahankan standar etika yang tinggi, menghidari etika tercela, menciptakan budaya komunikasi optimal dan melibatkan pihak lain dalam mempertahankan etika.

\section{SIMPULAN}

Hasil yang dicapai melalui kegiatan program pengabdian masyarakat untuk karang taruna diKelurahan Labuhbaru Barat;

1. Kecakapan individu dan sosial $90 \%$ peserta latih menunjukkan kategori "baik", 7,5\% berada pada kategori "cukup" dan hanya 2,5\% Peserta yang menunjukkan kategori "Kurang". $100 \%$ peserta latih menunjukkan disiplin dan semangat yang baik.

2. Setelah mengikuti pelatihan, peserta pelatihan telah memiliki kemampuan dalam aspek; (1) kecakapan personal yaitu mampu memelihara dan memperbaiki sepeda motor yang berkaitan dengan keterampilan mekanik antara lain meliputi; system tune up, system engine, system kelistrikan, dan system chasis, (2) kecakapan sosial yaitu memiliki kemampuan bekerjasama dengan unit usaha lain, memiliki kemampuan berkomunikasi dan negoisasi dengan pelanggan (customer), (3) kecakapan akademik yaitu memiliki kemampuan memecahkan masalah, misalnya jika terjadi kesalahan teknis dalam pemeliharaan dan perbaikan sepeda motor dan memiliki keberanian belajar dari kesalahan (trial and error). Dan (4) kecakapan Vocasional yaitu memiliki kemampuan dalam service kendaraan bermotor dalam waktu yang relatif singkat, atau kecepatan menyelesaikan satu produk jasa service sepeda motor. 
3. Kegiatan Pelatihan tune up berbasis tenhopreneur bagi pemuda karang taruna atau yang diselenggarakan atas kerjasama antara Lembaga Pengabdian pada Masyarakat UMRI dapat dinyatakan telah mencapai target luaran dengan indikator 15 orang peserta yang mengikuti kegiatan pelatihan dari awal sampai akhir telah memiliki kecakapan berupa keterampilan mekanik bidang otomotif yang dibutuhkan.

\section{DAFTAR PUSTAKA}

[1] Jusnita, dkk, 2018 Pelatihan Mekanik Sepeda Motor Untuk Anak Putus Sekolah Di Kelurahan Labuhbaru Barat Kecamatan Payung Sekaki Pekanbaru. Jurnal Pengabdian Untuk $\mathrm{Mu}$ negeRI Vol.1, No.1, November 2018

[2] Jusnita, dkk, 2017 Program Bengkel Dan Pelatihan Training Otomotif Di Kelurahan Labuhbaru Barat Kecamatan Payung Sekaki Pekanbaru, Jurnal Pengabdian Untuk $\mathrm{Mu}$ negeRI Vol.1, No.2, November 2017

[3] Ekawarna, dkk 2014 Khaidir Pelatihan Life Skill Bidang Otomotif Pada Pemuda Yang Tidak Melanjutkan Studi Di Kota Jambi, Jurnal Pengabdian pada Masyarakat Volume 29, Nomor 3 Juli September 2014

[4] Badan Pusat Statistik Kota Pekanbaru, (2014). KecamatanP ayung Sekaki Dalam Angka. 